\title{
POTENTIAL ADDED VALUE OF ARECA NUT PRODUCTS IN ACEH
}

\section{POTENSI PENINGKATAN NILAI TAMBAH PRODUK PINANG DI PROVINSI ACEH}

\author{
Miftahul Jannah"), Machfud, dan Sugiarto \\ Department of Agroindustrial Technology, Faculty of Agricultural Engineering and Technology, \\ IPB University, Bogor, Indonesia \\ *E-mail :miftaah1606@gmail.com
}

Makalah: Diterima 20 Januari 2021; Diperbaiki 20 Juli 2021; Disetujui 9 Agustus 2021

\begin{abstract}
ABSTRAK
Pengembangan agroindustri di Aceh dapat mendorong pertumbuhan ekonomi karena sumber utama pendapatan masyarakat Aceh berasal dari sektor pertanian. Penelitian ini bertujuan untuk mencari nilai tambah dan menemukan strategi terbaik untuk meningkatkan nilai tambah produk pinang. Penelitian ini menggunakan analisis nilai tambah, dimana output dikurangi biaya input dan analisis IFAS, EFAS dan SWOT untuk menentukan strategi terbaik untuk pengembangan agroindustry pinang. Hasil penelitian menunjukkan nilai tambah yang diperoleh dengan pengolahan pinnag menjadi tanin mencapai Rp 130.000 sedangkan pewarna alami mencapai Rp 105.000. Berdasarkan hasil analisis faktor internal dan eksternal menunjukkan bahwa factor internal lebih berpengaruh terhadap pengembangan agroindustry pinang dengan skor 3.00. Berdasarkan hasil model strategi kuantitatif, pengembangan agroindustri pinang dapat dilakukan dengan memaksimalkan peluang dan mengatasi segala faktor yang menjadi kelemahan. Oleh karena itu, strategi yang paling tepat untuk pengembangan produk potensial pinang adalah memfasilitasi dan mensosialisasikam informasi tentang produk turunan pinang kepada masyarakat serta mempromosikan dan meningkatkan inovasi teknologi untuk mempercepat adopsi teknologi oleh para petani.
\end{abstract}

Kata kunci: agroindustri, pinang, nilai tambah, analisis

\section{ABSTRACT}

The development and an improvement in agroindustry are essential to boost economic growth because the primary sources of low income's people are from agricultural sectors. This research aimed to measure the value addition and find the best strategy to add value of areca nut. This research used economical value-add formulation, which is the value of output less cost of inputs, IFAS, EFAS and SWOT analysis to ascertain the best strategy for development areca nut agroindustry. The result found out the value addition of areca tannin and natural dye were Rp 130.000 and Rp 105.000, respectively. Based on EFAS and IFAS analysis the total score of internal strategic factor was higher than external strategic factors, which were 3.00 and 2.53 , respectively. Therefore, developing the downstream products of areca nut can be improved by focusing on strategies to strengthen internal factors. Furthermore, based on the result of quantitative model of strategy, the development of areca nut agroindustry can be done by maximizing opportunities and overcoming all factors that become weaknesses. Therefore, the most suitable strategies for the development potential products of areca nut are facilitate and improve market information of areca nut downstream product for all of stakeholders and promoting and enhancing technological innovation to accelerate technological adoption of the farmers.

Keywords: agroindustry, areca nut, value addition, SWOT analysis

\section{INTRODUCTION}

Aceh regency has broad areca nut plantation areas which grows in all districts in Aceh province. The plantation area of areca nut in Aceh is 40.000 hectares that mainly cultivated by smallholder plantation farmers. In 2019, Indonesia export about 172.055 tonnes of dried nuts and Aceh contributed one-fifth of total areca nut export (Comtrade, 2020). Areca nut is mainly exported to other countries, such as India, Afghanistan, Pakistan, and China (Trade maps, 2020). The production of areca nut increases each year, but unfortunately, the government pays less attention to supporting areca nut cultivation and developing the areca nut industry in Aceh.
Areca nut or betel nut is one of the palm tree species which comprises four major parts, such as root, stem, leaf, and fruit (nut). Areca nut grown well in tropical countries such as Asia, Africa, and Pacific Islands, which is at about 14-36 degrees Celsius (Ali and Khuwaja, 2011). In general, Areca nut can be harvested three times a year, and the nut can live up to 30 years. Areca nut is used for many purposes, such as traditional medicines, furniture, cosmetics, foods, veterinary preparations, and textile industries (Chavan and Singhal, 2013). In Aceh, areca nut is well known for masticatory that chew with betel leaf and lime betel. It relates the betel chewing to social and cultural ceremonies such as the tradition of welcoming guests. 
The nut is the foremost part because of its trade and use in many industrial sectors. The nut contains some significant constituents such as carbohydrate, lipid, tannin and alkaloid. Areca nut contains a higher level of alkaloid, which will decrease as the nuts ripening. The unripe and ripe nut contains $0.062 \%$ and $0.14 \%$ alkaloid, respectively (Gupta $e t$ al., 2020). Alkaloid is mainly used as an antioxidant, astringent, and for many pharmaceutical purposes. Meanwhile, the lipid of areca nut can substitute the cocoa fat in the food industry (Chavan and Singhal, 2013).

Tannin is the most common substituent that can be found in almost all part of the plants. Tannin is a secondary metabolite from plants that primarily use a plant self-defence mechanism from the threats (Elok et al., 2010). Nowadays, the demand for natural material is increased because of the soar of back to nature and environmentally friendly substances (Aires et al., 2016). Tanning industries are one of the industrial concerns in reducing pollution and severe environmental damage. It is due to chromium usage in leather tanning processing, which causes a severe effect on human health (Abbas et al., 2013).

Areca nut industry can be developed in Aceh due to the number of benefits from the nuts, byproducts, and the great production of areca nut itself. Moreover, an improvement in agroindustry is essential to boost the economic growth in Aceh because the primary sources of Aceh people's income are from agricultural sectors. Unfortunately, the regulation and development planning on agroindustry is not implemented well, and somehow there is still vague. This condition hinders the development of agroindustry products that has high added value in Aceh. Therefore, this research aimed to calculate the amount of added value obtained from each product and identify the strengths, weaknesses, threats, and opportunities to determine the best strategy for development areca nut agroindustry.

\section{RESEARCH AND METHODS}

This research was conducted in Aceh province by interviewing areca nut agroindustry's stakeholders, such as farmers, traders, exporters, researchers, and the government. There are some analyses that employed in this research such as value add analysis, External and internal factor analysis, and SWOT Analysis.

\section{Value-added Analysis}

The value-added is defined as the difference between the output and input value from the products that has been processed (Sathre and Gustavsson, 2009). Adding value is foremost in the production process, which is generally related to financial value addition. In financial terms, the added value is the economic value generated by the products when they are changed within the production process (Vogel,
2011). To measure the value addition from each product, the author uses added value formulation by Kay (1995) below.

Value addition $=$ Output Price - Input Price

In this research, input means the price of the dried nuts in the market. Meanwhile, the output means the downstream products' selling price, which are tannin and natural dye. If the products have an output larger than input, it denotes as potential products to be developed.

\section{External Factor Analysis (EFAS) and Internal Factor Analysis (IFAS)}

The EFAS and IFAS matrices consist of a column of weights, ratings, and total values. For the weight and rating column is filled according to its value which is the result of a grouping of internal and external factors based on their importance. According to David (2009) the IFAS matrix is used to determine the internal factors of the company related to the strengths and weaknesses faced by the company consisting of aspects of human resources, marketing, production and operations, finance and accounting and information systems. The EFAS matrix is used to evaluate the external factors of the company. External data is collected to analyse matters concerning economic, political and governmental, socio-cultural, technological, environmental, demographic, competition in the industrial markets in which the company is located.

\section{SWOT Analysis}

SWOT analysis is a method for formulating the strategies by identifying strength, weakness, opportunity, and threat. Rangkuti (2006) claimed that the SWOT matrix could clearly describe how to grasp the opportunities and face the threats by maximising the strengths and realising the weaknesses they have. Adams (2005) divided four types of strategies that can be developed from SWOT analysis, such as:

- SO (Strength-Opportunities)

Strategies that company use by harnessing or optimising their power to facade existing opportunities.

- WO (Weakness-Opportunities)

The strategy used by the company to minimise the company's weaknesses by utilising existing opportunities.

- ST (Strength-Threats)

The strategy to optimise the company's internal strength to avoid or mitigate the impact of external threats.

- WT (Weakness-Threats) A defensive strategy developed to cover the company's internal weaknesses when facing external threats. 


\section{RESULT AND DISCUSSION}

\section{Value Added Calculation}

Added value $=$ Sales revenue $($ Unit $\mathrm{x}$ Price $)-$ Total cost (Raw material + Labour + Other production cost)

- Tanin

$$
\begin{aligned}
& \text { Tannin Price }=\operatorname{Rp~300.000/kg~} \\
& \text { Raw material }=\mathrm{Rp} 25.000 / \mathrm{kg} \\
& \text { (nut) } \\
& \text { Production }=\mathrm{Rp} 45.000 / \mathrm{kg} \text { tannin } \\
& \text { cost } \\
& \text { Value Add } \quad=\quad \mathrm{Rp} 300.000-[(\mathrm{Rp} \\
& 25.000 \times 5)+\operatorname{Rp} 45.000] \\
& =\quad \operatorname{Rp} 300.000-\operatorname{Rp} 170.000 \\
& =\operatorname{Rp} 130.000
\end{aligned}
$$

- Natural Dye

$$
\begin{aligned}
& \text { Natural dye }=\operatorname{Rp} 210.000 / \mathrm{Kg} \\
& \text { price } \\
& \text { Raw material }=\operatorname{Rp~} 25.000 / \mathrm{kg} \text { and need } 3 \\
& \text { (nut) } \\
& \text { Production } \quad=\operatorname{Rp~30.000/kg~natural~dye~} \\
& \text { cost } \\
& \text { Value Add } \quad=\quad \operatorname{Rp} 210.000-[(\mathrm{Rp} \\
& 25.000 \times 3)+R p \text { 30.000] } \\
& =\mathrm{Rp} 210.000-\mathrm{Rp} \\
& 1105.000 \\
& =\operatorname{Rp} 105.000
\end{aligned}
$$

\section{Value Added Analysis}

Based on value-added calculation on Table 1, tannin and natural dye might derive the value addition more than the raw nut. Moreover, adding utility value to raw materials is an important goal of industrial activity. Industrial processing has more excellent exchange value by transforming the raw material into preferred products in the market. Adding exchange value generally accompanies utility value, although the quantification is difficult to compare in heterogeneous goods (Sathre and Gustavson, 2009).

Table 1. Value addition of tannin and natural dye

\begin{tabular}{lccc}
\hline Products & $\begin{array}{c}\text { Input } \\
(\mathbf{R p})\end{array}$ & $\begin{array}{c}\text { Output } \\
(\mathbf{R p})\end{array}$ & $\begin{array}{c}\text { Value Added } \\
\text { (Rp) }\end{array}$ \\
\hline Tannin & 300.000 & 170.000 & 130.000 \\
Natural & 210.000 & 105.000 & 105.000 \\
Dye & & & \\
\hline
\end{tabular}

\section{Tannin Potential}

Tannin is widely used in the textiles, foods, and pharmaceutical industries. It can utilize tannin as wood adhesive, tanner, and antioxidant sources. Nowadays, the demand for natural material is increased because of the soar of back to nature, and environmentally friendly substances need (Aires et al., 2016). Tanning industries are one of the industrial concerns in reducing pollution and severe environmental damage. It is due to chromium usage in leather tanning processing, which causes a severe effect on human health (Abbas et al., 2013). Vegetable tanning with an appropriate extraction method can replace chromium because of the less harmful and renewable origin. It might be a leeway for the environmental problem caused by the leather tanning industry (Seabra et al., 2018).

Based on Grand View Research (2017) Leather industry has a bright future due to the increasing demand for footwear, jacket, belt and other products based on leather. They forecast it increases at about $9.5 \%$ of CAGR from 2016 to 2015. Therefore, the tannin industry also forecasted will reach a significant amount of market demand at about USD 3.39 million by 2025 (Grand View Research, 2017). Currently, leather tanning production processes in Indonesia still use chromium sulphate and vegetable tanners from mimosa as a tanning agent. Chromium sulphate is harmful to the environment, while mimosa is relatively expensive because it is still imported (Ardinal et al., 2013). The areca tannin has a magnificent prospect due to the availability of raw material. Furthermore, the advanced technology might be adopted to improve the yield quality and quantity of areca tannin itself (Aires et al., 2016).

On the other hand, the increasing demand for tannin in the European and North American market provides an opportunity for the tannin industry to expand their business. Tannin has an antioxidant substituent that is foremost to improve the quality of wine production. Meanwhile, the Asia Pacific market shows the fostered tannin market for leather tanning and the food and beverages industry (Grand View Research, 2017).

\section{Natural dye Potential}

Natural dyes have been recommended as a colouring-agent that are friendly both for the environment and health. The substituents are low pollution, biodegradable, and not poisonous. Nowadays, the thrive of using eco-friendly material pushes the industries to produce natural based products for various purposes, such as textile colouration, antifeedant finishing textile, cosmetic and pharmaceutical, dye-sensitized, and food colouration. Commonly, natural dyes derived from agriculture's primary products, such as fruits or leaves that potentially produce some colour, by-product of farming or forestry, and waste of food and beverage industries (Shahid et al., 2013).

In the last decades, synthetic dye still dominated the textile industry because of the abundant variation and attractive colour. Moreover, the synthetic dye is more affordable and more applicable in many fabrics make people doubt the sustainability of natural dye (Fangueiro and Rana, 2016). However, there is some drawback from using synthetic dye, particularly for the environment and human health. Therefore, natural dye is such a leeway 
to prevent the devastating impact of waste in the industrial industry (Shahid et al., 2013).

Nowadays, the global market demands of natural dye explode at about 10.000 tonnes per years (Shivakumar et al., 2010). Businesswire (2020) research forecast that the natural dye industry might generate revenue at about $\$ 5$ billion by 2024 , a growth of around $18 \%$ at CAGR. This phenomenon is driven by the increasing of awareness on sustainable environment and highly concern for healthy lifestyles. Likewise, the advanced technology enables natural dye to compete with the synthetic dye industries. The ultrasound method is potentially used to extract natural colourant sources from many parts of various plants (Shivakumar et al., 2010).

Moreover, the textile industry's plasma treatment may enhance the quality of natural dye in the fabrication (Haji and Naebe, 2020). On the other hand, some people are highly concerned about environmental issues, forcing the industry to use the eco-friendly material.

Furthermore, the natural dye industry has a delightful prospect to be developed in Indonesia. This is because of the increasing demand for natural colourant for the batik industry as one of the heritage textile industries that use many colour variations (Purwanto, 2018). Prabawa (2015) proved that the colourant from areca nut seed is a compatible dyeing for the Sasirangan industry, one of the leading regional textile products in South Kalimantan. Furthermore, Yernisa et al. (2013) also show that the powder of areca seed potentially uses in transparent soap industry. This finding attests to a promising future for the natural dye industry.

Table 2. EFAS and IFAS Matrix

\begin{tabular}{|c|c|c|c|c|}
\hline & EFAS and IFAS Matrix & $\begin{array}{l}\text { Weighted } \\
\text { Factors }\end{array}$ & Rating & $\begin{array}{l}\text { Total } \\
\text { Scores }\end{array}$ \\
\hline \multicolumn{5}{|c|}{ Opportunity } \\
\hline 1 & Market demand of areca nut downstream products & 0.05 & 3 & 0.16 \\
\hline 2 & Government Support to SMEs & 0.08 & 3 & 0.24 \\
\hline 3 & Enhancement on Technology and exchange information & 0.11 & 4 & 0.42 \\
\hline 4 & $\begin{array}{l}\text { Research and development on agricultural downstream } \\
\text { products }\end{array}$ & 0.13 & 3 & 0.39 \\
\hline 5 & Raising awareness on environmental issues & 0.13 & 4 & 0.53 \\
\hline \multicolumn{2}{|r|}{ Total } & & & 1.74 \\
\hline \multicolumn{5}{|c|}{ Threat } \\
\hline 1 & Lack of creativity and productivity in SMEs & 0.05 & 2 & 0.11 \\
\hline \multirow{2}{*}{$\begin{array}{l}2 \\
3\end{array}$} & Areca nut Export should use intermediate countries & 0.11 & 2 & 0.21 \\
\hline & $\begin{array}{l}\text { Politics and economics issues that influence the investor to } \\
\text { invest in Aceh }\end{array}$ & 0.13 & 1 & 0.13 \\
\hline 4 & Competitor from synthetic product & 0.13 & 2 & 0.26 \\
\hline \multirow[t]{3}{*}{5} & No association of areca nut stakeholder & 0.08 & 1 & 0.08 \\
\hline & Total & 1.00 & & 0.79 \\
\hline & Total EFAS & & & 2.53 \\
\hline \multicolumn{5}{|c|}{ Strength } \\
\hline 1 & The availability of Raw material & 0.09 & 4 & 0.36 \\
\hline 2 & Strategic geographical Area & 0.09 & 3 & 0.27 \\
\hline 3 & Government intention to support the agricultural products & 0.06 & 3 & 0.18 \\
\hline 4 & The availability of human resources or Labour force & 0.15 & 2 & 0.30 \\
\hline 5 & Suitable land for areca nut cultivation & 0.06 & 3 & 0.18 \\
\hline \multicolumn{2}{|r|}{ Total } & & & 1.30 \\
\hline \multicolumn{5}{|c|}{ Weakness } \\
\hline 1 & Traditional processing which causes post harvested losses & 0.15 & 3 & 0.45 \\
\hline 2 & $\begin{array}{l}\text { No adequate technology to process raw material into high } \\
\text { value add products }\end{array}$ & 0.06 & 3 & 0.18 \\
\hline 3 & Price fluctuation & 0.06 & 2 & 0.12 \\
\hline 4 & Low quality of human resource & 0.15 & 3 & 0.45 \\
\hline \multirow[t]{3}{*}{5} & Lack of market price information & 0.12 & 4 & 0.48 \\
\hline & Total & 1.00 & & 1.70 \\
\hline & Total IFAS & & & 3.00 \\
\hline
\end{tabular}


One potential plant as sources of natural dyes is Areca nut, which has others function as consumption, industrial materials, cosmetics, health, and colouring matter in the textile industry (Miftahorrachman and Maskromo, 2007). Bogariani (2009) found that a mixture of natural dyes from gambier, Betel leaf and areca nut produces light brown to reddish-brown colour. According to Sulastri (2009), dyes from Areca nut seed extract are part of the tannin group highly contained in areca nut seed.

\section{External Factor Analysis (EFAS) and Internal Factor Analysis (IFAS)}

The Table 2 below show the result of external and internal factor analysis in the development potential products of areca nut. Based on EFAS and IFAS analysis on the table 2, the total score internal strategic factor is 3.00 , whereas the score of external strategic factors is 2.53 . Therefore, developing the downstream products of areca nut can be improved by focusing on strategies to strengthen internal factors. The development of the areca nut agroindustry in Aceh has the potential to be improved because of the abundance of raw materials and the availability of human resources or Labour force. So that, it can be the main force for the development of areca nut-based products in Aceh province. However, the lack of market information and also technological mastery should be addressed to enhance areca nut agroindustry in Aceh.

Table 3. SWOT analysis matrix

\begin{tabular}{|c|c|c|}
\hline EXTERNAL & $\begin{array}{ll}\text { STRENGTH } \\
\text { 1. } \\
\text { Market demand of areca nut } \\
\text { downstream products } \\
\text { 2. } \begin{array}{l}\text { Government Support to } \\
\text { SMEs }\end{array} \\
\text { 3. } \begin{array}{l}\text { Enhancement on } \\
\text { Technology and exchange } \\
\text { information }\end{array} \\
\text { 4. Research and development } \\
\text { on agricultural downstream } \\
\text { products } \\
\text { 5. Raising awareness on } \\
\text { environmental issues }\end{array}$ & \begin{tabular}{|l} 
WEAKNESS \\
1. $\begin{array}{l}\text { Traditional processing which } \\
\text { causes post harvested losses }\end{array}$ \\
2. $\begin{array}{l}\text { No adequate technology to } \\
\text { process raw material into }\end{array}$ \\
high value add products \\
3. $\begin{array}{l}\text { Price fluctuation } \\
\text { 4. }\end{array}$ \\
$\begin{array}{l}\text { Low quality of human } \\
\text { resource } \\
\text { 5ack of market price } \\
\text { information }\end{array}$
\end{tabular} \\
\hline $\begin{array}{l}\text { OPPORTUNITIES } \\
\text { 1. The availability of Raw } \\
\text { material } \\
\text { 2. Strategic geographical Area } \\
\text { 3. } \begin{array}{l}\text { Government intention to } \\
\text { support the agricultural } \\
\text { products }\end{array} \\
\text { 4. The availability of human } \\
\text { resources or Labour force } \\
\text { 5. Suitable land for areca nut } \\
\text { cultivation }\end{array}$ & $\begin{array}{l}\text { S-O Strategy } \\
\text { 1. } \\
\text { Development of various } \\
\text { natural-based products of } \\
\text { areca nut agroindustry. } \\
\text { 2. } \\
\begin{array}{l}\text { Stimulate and enhance the } \\
\text { ability of SMEs based } \\
\text { processing industry. }\end{array}\end{array}$ & 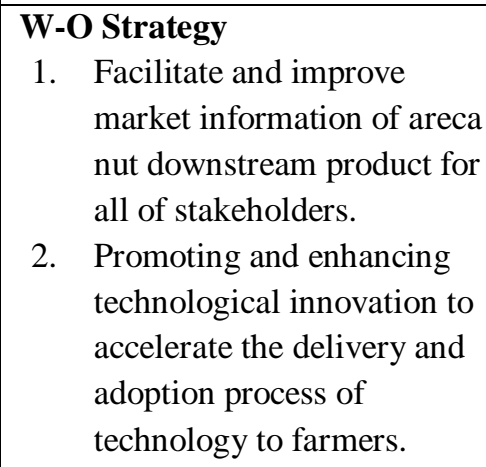 \\
\hline $\begin{array}{l}\text { THREATS } \\
\text { 1. Lack of creativity and } \\
\text { productivity in SMEs } \\
\text { 2. Areca nut Export should use } \\
\text { intermediate countries } \\
\text { 3. Politics and economics issues } \\
\text { that influence the investor to } \\
\text { invest in Aceh } \\
\text { 4. Competitor from synthetic } \\
\text { product } \\
\text { 5. No association of areca nut } \\
\text { stakeholder }\end{array}$ & $\begin{array}{l}\text { S-T Strategy } \\
\text { 1. Strengthen the coordination } \\
\text { among areca nut } \\
\text { stakeholders } \\
\text { 2. } \begin{array}{l}\text { Enhance creativity and } \\
\text { productivity in SMEs to } \\
\text { create new product and }\end{array} \\
\text { employ local labour forces. } \\
\text { 3. Improvement of product } \\
\text { competitiveness and } \\
\text { diversification }\end{array}$ & $\begin{array}{l}\text { W-T Strategy } \\
\text { 1. Having a regulation or } \\
\text { policy that may convince } \\
\text { the investor to invest in } \\
\text { Aceh. } \\
\text { 2. Development of extension } \\
\text { programs based on farmers } \\
\text { need. }\end{array}$ \\
\hline
\end{tabular}


Table 3. Quantitative model of strategy calculation

\begin{tabular}{lll}
\hline IFE/EFE & Strength & Weakness \\
\hline Opportunities & S-O Strategy & W-O Strategy \\
& $=$ Strength + Opportunities & $=$ Weakness + Opportunities \\
& $=1.30+1.74$ & $=1.74+1.70$ \\
& $=3.04$ & $=3.44$ \\
Threats & S-T Strategy & W-T Strategy \\
& $=$ Strength + Threats & $=$ Weakness + Threats \\
& $=0.79+1.30$ & $=0.79+1.70$ \\
& $=2.09$ & $=2.49$ \\
\hline
\end{tabular}

\section{Quantitative Model of Strategy Formulation}

According to the results of the analysis using quantitative model of strategy, WO strategy obtained the highest value of 3.44 (Table 3). Therefore, the development of agroindustry can be done by maximizing opportunities and overcoming all factors that become weaknesses. In such conditions, the stakeholders of areca nut agroindustry have two strategies that can be used, namely facilitate and improve market information of areca nut downstream product for all of stakeholders and promoting and enhancing technological innovation to accelerate technological adoption of the farmers.

\section{CONCLUSIONS AND RECOMMENDATION}

\section{Conclusions}

To sum up, Areca nut the development of areca nut downstream products in Aceh is feasible. It may prosper of all areca nut stakeholders due to the increasing awareness of sustainable environment and highly concern on healthy lifestyles. Tannin and Natural Dyes are the most potential product to be developed because of the market demand and added value for those relatively high. The result found out the value addition of areca tannin and natural dye are Rp 130.000 and Rp 105.000, respectively. Based on EFAS and IFAS analysis the total score internal strategic factor is higher than external strategic factor, which are 3.00 and 2.53 , respectively. Therefore, developing the downstream products of areca nut can be improved by focusing on strategies to strengthen internal factors. The development of the areca nut agroindustry in Aceh has the potential to be improved because of the abundance of raw materials and the availability of human resources or Labour force. So that, it can be the main force for the development of areca nut-based products in Aceh province. However, the lack of market information and also technological mastery should be addressed to enhance areca nut agroindustry in Aceh. Furthermore, based on the result of quantitative model of strategy, the development of areca nut agroindustry can be done by maximizing opportunities and overcoming all factors that become weaknesses.
The development of the areca nut industry might be a leeway to improve farmer prosperity and provide new entrepreneurs opportunities to thrive in their business. Moreover, raising awareness of environmental issues is the key to adding value to areca nut downstream products. On the other hand, Farmers are the main factors that determine the success of agro-industrial development. Therefore, the development of farmer-based extension programs is the most acceptable strategy to support the process of potential actualization and absorption of innovation by farmers to ensure agro-industrial development sustainability. By considering the shortcomings and challenges such as on-farm problems, assessing appropriate technology, providing training so that workers can operate technology, and increasing cooperation between stakeholders might increase the affordability and visibility of the areca nut downstream products industry.

\section{Recommendation}

This research provides some alternatives for the development of areca nut potential products based on the simplicity of technology and market demand for tannin and natural dyes. It will be better if there is further research to evaluate the feasibility and viability on other areca nuts products.

\section{REFERENCES}

Abbas M, Rahma MA, and Safdar A. 2013. Detection of Heavy Metals Concentration Due to Leather Tanning Industry and Prevalent Disease Pattern in Kasur, Pakistan. Environment and Urbanization ASIA. 3(2): 375-384.

https://doi.org/10.1177/0975425312473233

Aires A, Carvalho R, and Saavedra MJ. 2016. Valorization of solid wastes from chestnut industry processing: Extraction and optimization of polyphenols, tannins and ellagitannins and its potential for adhesives, cosmetic and pharmaceutical industry. Waste Management. 4(8): 457-464.

Ali NS and Khuwaja AK. 2011. Betel nut (areca catechu) usage and its effects on health. Nuts 
and Seeds in Health and Disease Prevention. 7(8): 197-204.

Ardinal AK dan Mutiar S. 2013. Karakteristik penyamakan kulit menggunakan gambir pada $\mathrm{pH} 4$ dan 8. Jurnal Biopropal Industri. 4(2): 81-85.

Bogoriani NW dan Bawa Putra AA. 2009. Perbandingan massa optimum campuran pewarna alami pada kayu jenis akasia (Acacia Leucopholea). Jurnal Kimia. 3(1): 21-26.

[BPS] Badan Pusat Statistik. 2015. Data produksi dan luas perkebunan pinang. [retrived 3 June 2019].

https://www.bps.go.id/indicator/54/94/1/pro duksi-perkebunan-besar-menurut-jenistanaman.html

Bussinesswire. 2020. The Global Market for Natural Dyes, 2019 to 2024. [retrieved 1 May 2019].https://www.businesswire.com/news/ home/20190224005075/en/Global-MarketNatural-Dyes-2019-2024-- .

Chavan Y and Singhal RS. 2013. Ultrasound-assisted extraction (UAE) of bioactives from arecanut (Areca catechu L.) and optimization study using response surface methodology. Innovative Food Science \& Emerging Technologies. 17(3): 106-113.

Comtrade. 2019. Nuts, Edible; Edible Areca Nuts; Fresh or Dried Wheter or no Shelled or Peeled. [retrieved 3 January 2020]. https://comtrade.un.org/data/.

David RF. 2009. Manajemen Strategi Konsep. Jakarta: Salemba empat.

Djufri F. 2015. Teknologi Budidaya dan Pasca Panen Pinang. Manado: Balai Penelitian Tanaman Palma.

Elok KH, Ghanaim F, dan Lailis S. 2010. Fraksinasi dan identifikasi senyawa tanin pada daun belimbing wuluh (Averrhoa bilimbi L.) Jurnal Kimia. 4 (2): 193-200.

Fangueiro R dan Rana S. 2016. Natural fibres: advances in science and technology towards industrial applications. [Edited] Springer.

[FAOSTAT] Food and Agriculture Organization Corporate Statistical Database. 2010. Topical palm. [retrieved 25 July 2020]. http://www.fao.org/3/i1590e/i1590e.pdf.

Ferry Y. 2003. Strategi pengembangan pinang di Nanggroe Aceh Darussalam. Warta Penelitian dan Pengembangan Tanaman Industry. 9(2): 1-4.

Gupta AK, Tulsyan S, Thakur N, Sharma V, Sinha DN, Mehrotra R. 2020. Chemistry, metabolism and pharmacology of carcinogenic alkaloids present in areca nut and factors affecting their concentration. Regul Toxicol Pharmacol. 110(10): 45-58.

[GVR] Grand View Research. 2017. Tannin market size to reach $\$ 3.39$ billion by 2025 / growth rate: $6.7 \%$.. [retrieved 3 February 2020] .https://www.grandview research./org.

Haji A and Naebe M. 2020. Cleaner dyeing of textiles using plasma treatment and natural dyes: A review. Journal Cleaner Production. 3 (4): 244-265.

Kay J. 1995. Foundations of Corporate Success How Business Strategies Add Value. London: Oxford University Press.

Masur JS. 2021. Chevronizing around cost benefit analysis. Duke Law Journal. 70(5): 11091151.

Miftahorrachman M dan Maskromo I. 2017. Analisis jarak fenotipik dan potensi produksi enam aksesi pinang asal Provinsi Jambi. Buletin Palma. 3(6): 91-99.

Mineraud J, Mazhelis O, Su X, Tarkoma S. 2016. A gap analysis of internet of thing's platforms. Computer Communications. 89 (2): 5-16.

Prabawa IDGP. 2014. Ekstrak biji buah pinang sebagai pewarna alami pada kain sasirangan. Jurnal Riset Industri Hasil Hutan. 7(2): 31-38.

Purwanto. 2018. Prosiding Seminar Nasional Aplikasi Sains \& Teknologi (SNAST) 2018 ISSN: 1979-911X Yogyakarta, 15 September 2018. Access on 28 July 2020

Rangkuti F. 2006. Analisis SWOT: Teknik Membedah Kasus Bisnis - Reorientasi Konsep Perencanaan Strategis Untuk Menghadapi Abad 21. Jakarta: PT Gramedia Pustaka Utama.

Sathre R and Gustavsson L. 2009. Process- based analysis of added value in forest product industries. Forest Policy and Economics. 11(1): 65-75.

Seabra IJ, Chim RB, Salgueiro P, Braga MEM, De Sousa HC. 2018. Influence of solvent additives on the aqueous extraction of tannins from pine bark: potential extracts for leather tanning. Journal Chemical Technology \& Biotechnology. 93(4): 11691182.

Shahid M, Shahid UI, and Mohammad F. 2013. Recent advancements in natural dye applications: a review. Journal Cleaner Production. 53 (2): 310-331.

Shivakumar V, Vijaeeswarri J, and Anna JL. 2011. Effective natural dye extraction from different plant materials using ultrasound. Industrial Crops and Products. 33(1): 116-122.

Sulastry T. 2009. Analisis kadar tanin ekstrak air dan ekstrak etanol pada biji pinang sirih (Areca Catechu. L). Chemica: Jurnal Ilmiah Kimia dan Pendidikan Kimia. 10(1): 59-63.

Trade Maps. 2019. Share of exporting market. [retrieved 4 April 2020]. https://www.trademap.org/. 
Vogel HA. 2011. Do privatized airports add financial value? Research in Transportation Business \& Management. 1 (1): 15-24.

Yernisa, Gumbira-Sa'id E, and Syamsu K. 2013. Application of Natural Powders from Areca
Catechu L. Extract on Transparent Soap Stain. Journal Agricultural Industrial Technology. 23(3): 190-198. 